\title{
PELAKSANAAN KESELAMATAN PASIEN \\ OLEH PERAWAT
}

\section{Nur Aini Lubis}

\section{Email: nrnlubis@gmail.com}

\section{Latar Belakang:}

Keselamatan Pasien (KP) adalah suatu sistem dimana rumah sakit membuat asuhan pasien lebih aman, mencegah terjadinya cedera yang disebabkan oleh kesalahan akibat melaksanakan suatu tindakan atau tidak mengambil tindakan yang seharusnya diambil. Pada prinsipnya keselamatan pasien bukan berarti harus tidak ada risiko sama sekali agar semua tindakan medis dapat dilakukan.

Perawat sebagai ujung tombak pemberi pelayanan kesehatan merupakan hal yang penting untuk dikaji dalam rangka mempertahankan dan meningkatkan mutu pelayanan kesehatan. Kinerja yang baik merupakan jembatan dalam menjawab kualitas pelayanan kesehatan yang diberikan terhadap pasien baik yang sakit maupun yang sehat (Murdyastuti, 2010).

Rumah sakit sebagai tempat penyelenggaraan pelayanan kesehatan yang bersifat penyembuhan (kuratif) dan pemulihan (rehabilitative) mempunyai potensi yang besar dalam penularan atau penyebaran penyakit, baik dari pasien ke tenaga kesehatan atau sebaliknya, dari pasien ke alat/fasilitas kesehatan atau sebaliknya, dan dari tenaga kesehatan ke alat/fasilitas kesehatan.

Organisasi kesehatan dunia WHO (World Health Organization) juga telah menegaskan pentingnya Keselamatan dalam pelayanan kepada pasien: "Safety is a fundamental principle of patient care and a critical component of quality management."

Dalam rangka meningkatkan keselamatan pasien di rumah sakit maka Perhimpunan Rumah Sakit Seluruh Indonesia (PERSI) telah mengambil inisiatif membentuk Komite Keselamatan Pasien Rumah Sakit (KKPRS) pada tanggal 1 Juni 2005. Komite tersebut telah aktif melaksanakan langkah langkah persiapan pelaksanaan keselamatan pasien rumah sakit dengan mengembangkan laboratorium program keselamatan pasien rumah sakit. Selanjutnya Gerakan Keselamatan Pasien Rumah Sakit ini kemudian dicanangkan oleh Menteri Kesehatan pada Seminar Nasional PERSI pada tanggal 21 Agustus 2005, di Jakarta Convention CentreJakarta.(KPP-RS, 2012).

KKPRS telah menyusun Panduan sembilan Langkah Menuju Keselamatan Pasien untuk mengimplementasikan Keselamatan Pasien di rumah sakit. Di samping itu pula KARS 
(Komite Akreditasi Rumah Sakit) Departemen Kesehatan telah menyusun Standar Keselamatan Pasien Rumah Sakit yang akan menjadi salah satu Standar Akreditasi. (KPPRS, 2012).

Mengingat keselamatan pasien sudah menjadi tuntutan masyarakat maka pelaksanaan program keselamatan pasien rumah sakit perlu dilakukan. Berkaitan dengan tuntutan keselamatan pasien tersebut maka diperlukan acuan yang jelas untuk melaksanakan keselamatan pasien tersebut. Buku Panduan Nasional Keselamatan Pasien Rumah Sakit yang terutama berisi Standar Keselamatan Pasien Rumah Sakit dan Tujuh Langkah Menuju Keselamatan Pasien Rumah Sakit diharapkan dapat membantu rumah sakit dalam melaksanakan kegiatannya.(Depkes RI, 2006).

Keselamatan pasien sebagai suatu sistem diharapkan memberikan asuhan kepada pasien lebih aman,mencegah cedera akibat kesalahan karena melakukan tindakan atau tidak melakukan tindakan yang seharusnya dilakukan. Keselamatan pasien juga merupakan suatu sistem dimana rumah sakit membuat asuhan pasien lebih aman.

\section{Metode}

Pengumpulan data dengan menggunakan kuesioner/ angket sebagai alat pengumpulan data berdasarkan panduan nasional keselamatan pasien (Patient Safety) yang disusun oleh Komite Akreditasi Rumah Sakit Departemen Kesehatan. Kuesioner berisi daftar pertanyaan berjumlah 9 item total pernyataan 45. Pernyataan mengacu pada Sembilan solusi.

\section{Hasil Dan Pembahasan}

Perencanaan pelayanan dibuat dengan alasan sebagai acuan atau pedoman bagi dokter atau perawat ketika hendak memberikan tindakan kepada pasien agar sesuai dengan kondisi yang sedang dialami pasien itu sendiri.

Pemenuhan standar hak pasien juga salah satunya dengan memberikan penjelasan yang lengkap, benar dan jelas kepada pasien dan keluarganya terkait dengan tindakan dan segala resiko yang akan dialami pada saat diberikan pelayanan tanpa menambah-nambah ataupun mengurangi penjelasan karena hal ini berkaitan dengan nyawa dari pasien itu sendiri.

Hak pasien yang dimaksudkan disini adalah pasien maupun keluarganya berhak untuk mendapatkan informasi tentang rencana dan hasil pelayanan termasuk kemungkinan terjadinya insiden.

Dampak positif dari pemenuhan hak pasien adalah pasien mengetahui tentang diagnosis yang dilakukan oleh dokter kepadanya serta resiko-resiko yang akan terjadi dari tindakan medis yang dilakukan serta mengetahui alternatif terapi untuk kepentingan penyembuhannya. 
Keselamatan pasien dapat juga ditingkatkan dengan menjalin komunitasi antar tim baik Dokter dengan perawat atau dengan pasien. Komunikasi dalam dunia kesehatan adalah pengiriman pesan antara pengirim danpenerima dengan interaksi diantara keduanya yang bertujuan menumbuhkan kepercayaan,menyebabkan keamanan menimbulkan kepuasan, meningkatkan pengobatan yang menuju kesembuhan, karena didalam komunikasi saling memberi dan menerima antara pasien dan petugas kesehatan.

Berdasarkan Permenkes RI Nomor 11 Tahun 2017 tentang Keselamatan Pasien bahwa keselamatan dalam memberikan pelayanan dapat ditingkatkan dengan keterlibatan pasien yang merupakan partner dalam proses pelayanan. Oleh karena itu, maka fasilitas kesehatan harus memiliki sistem dan mekanisme mendidik pasien dan keluarganya mengenai kewajiban dan tanggungjawab dalam asuhan pasien. Dengan pendidikan tersebut diharapkan pasien dan keluarganya dapat berpartisipasi dengan baik, dan mendapat informasi dalam mengambil keputusan tentang asuhan yang diterimanya.

Terdapat tujuh standar keselamatan pasien yang di atur melalui Peraturan Menterian Kesehatan, yaitu:

1. Hak Pasien

Pasien dan keluarganya berhak memperoleh informasi terkait rencana tindakan, hasil pelayanan dan kemungkinan terjadinya insiden. Untuk memuhi standar ini maka terdapat sejumlah kriteria yang harus dipenuhi:

a. Harus ada dokter penanggungjawab pelayanan

b. Dokter penanggungjawab elayanan wajib membuat rencana pelayanan,serta

c. Dokter penanggung jawab wajib memberikan penjelasan yang komprehensif tentang rencana, prosedur, pengobatan dan hasil pelayanan.

2. Mendidik pasien dan keluarga

Rumah sakit bertugas untuk mendidika pasien dan keluarganya tentang kewajiban dan tanggungjawab pasien dalam asuhan pasien. Rumah sakit diharapkan memiliki mekanisme dalam hal ini, output dari standar ini adalah pasien dan keluarga diharapkan dapat:
a. Memberikan informasi yang benar, jelas, lengkap dan jujur.
b. Mengetahui kewajiban dan tanggungjawab pasien dan keluarga.
c. Dapat mengajukan pertanyaan apabila ada hal yang tidak dimengerti.
d. Memahami dan menerima konsekuensi dari pelayanan.
e. Mematuhi aturan dan instruksi yang diberikan.
f. Memiliki sikap menghormati dan tenggang rasa,serta 


\section{g. Memnuhi kewajiban finansial}

3. Keselamatan pasien dalam kesinambungan pelayanan Dalam hal ini rumah sakit menjamin keselamatan pasien dengan memastikan koordinasi antar tenaga kesehatan dan antar unit dalam rangka kesinambungan pelayanan. Hal ini dapat dilihat dari :

a. Adanya koordinasi pelayanan secara komprehensif mulai dari saat pasien masuk, pemeriksaan, diagnosis, perencanaan pelayanan, tindakan pengobatan, rujukan dan saat pasien keluar dari rumah sakit.

b. Adanya koordinasi pelayanan yang disesuaikan dengan kebutuhan pasien dan kelayakan sumber daya secara berkesinambungan sehingga pada seluruh tahap pelayanan transisi antar unit pelayanan dapat berjalan baik dan lancar.

c. Adanya koordinasi pelayanan termasuk didalamnya peningkatan komunikasi dalam rangka memfasilitasi dukungan keluarga, pelayanan keperawatan, pelayanan sosial, konsultasi dan rujukan, pelayanan kesehatan primer dan tindak lanjut lainnya.

d. Antar profesi kesehatan terjalin komunikasi dan transfer informasi.

4. Penggunaan metode peningkatan kinerja untuk melakukan evaluasi dan program peningkatan keselamatan pasien Pada standar ini rumah sakit diharapkan mampu mendesain proses baru atau memperbaiki proses yang ada dalam rangka meningkatkan kinerja dan keselamatan pasien. Hal ini dapat dilihat dari:

a. Rumah Sakit melakukan proses perancangan yang baik yang mengacu kepada kebutuhan pasien, kaidah klinis, dan faktor-faktor lain yang berpotensi menimbulkan risiko.

b. Rumah Sakit harus melakukan pengumpulan data kinerja yang terdiri dari pelaporan insiden,akreditasi, manajemen risiko, utilisasi, mutu pelayanan dan keuangan.

c. Rumah sakit harus melakukan evaluasi terhadap insiden.

d. Rumah sakit menentukan perubahan sistem dengan berbasis kepada data dan indormasi hasil analisis.

5. Peran kepemimpinan dalam meningkatankan keselamatan pasien:

a. Pemimpin mendorong dan menjamin implementasi program keselamatan pasien.

b. Pemimpin menjamin berlangsungnya kediatan identifikasi resiko terhadap keselamatan pasien.

c. Pemimpin mengalokasikan sumberdaya yang kuat.

d. Pemimpin mengukur dan mengkaji efektifitas kontribusinya.

6. Mendidik staf tentang keselamatan pasien

a. Memiliki proses pendidikan, pelatihan dan orien $\square$ tasi untk setiap jabatan; dan 
b. Menyelenggarakan pendidikan dan juga pelatihan yang berkelanjutan.

7. Komunikasi sebagai kunci efektif,serta

a. Merencanakan dan mendesain proses manajemen informasi terkait keselamatan pasien, dan

b. Transmisi data dan informasi akurat dan tepat waktu.

Terjadinya insiden keselamatan pasien di dalam rumah sakit sekecil apapun harus segera ditangani, jika tidak, hal ini akan memberikan dampak yang merugikan bagi pihak rumah sakit, staf rumah sakit, dan pasien sendiri sebagai penerima jasa pelayanan. Adapun dampak yang ditimbulkan antara lain adalah dapat menurunkan tingkat kepercayaan masyarakat terhadap pelayanan kesehatan karena rendahnya pelayanan yang diberikan kepada pasien. salah satu hal yang dapat dilakukan untuk meminimalisir terjadinya insiden keselamatan pasien adalah dengan cara identifikasi risiko insiden tersebut, sehingga staf rumah sakit akan mengetahui akar dari permasalahan tersebut.

Keselamatan pasien juga dapat didukung dengan menerapkan Metode-metode yang dapat meningingkatkan Keselamatan pasien (nine saving safety Solution) yaitu :

1. Perhatikan Nama Obat, Rupa dan Ucapan Mirip (Look-Alike, Sound-Alike Medication Names).

2. Pastikan Identifikasi Pasien.

3. Komunikasi Secara Benar saat Serah Terima / Pengoperan Pasien.

4. Pastikan Tindakan yang benar pada Sisi Tubuh yang benar.

5. Kendalikan Cairan Elektrolit Pekat (Concentrated).

6. Pastikan Akurasi Pemberian Obat pada Pengalihan Pelayanan.

7. Hindari Salah Kateter dan Salah Sambung Slang (Tube).

8. Gunakan Alat Injeksi Sekali Pakai.

9. Tingkatkan Kebersihan Tangan (Hand Hygiene) untuk Pencegahan lnfeksi Nosokomial.

\section{Saran Dan Kesimpulan}

Keselamatan Pasien adalah Suatu Sistem dimana Rumah Sakit adalah tempat asuhan keperawatan dimana pasien lebih akan aman, mencegah terjadinya cedera yang disebabkan oleh kesalahan akibat melaksanakan suatu tindakan atau tidak mengambil tindakan yang seharusnya diambil. Dan perawat bertugas sebagai pemberi layanan asuhan keperawatan terhadap pasien dimana perawat harus bekerja profesional dengan memperhatikan resiko keselamatan pasien berdasarkan Permenkes RI Nomor 11 Tahun 2017 tentang Keselamatan Pasien bahwa keselamatan dalam memberikan pelayanan dapat ditingkatkan dengan keterlibatan pasien yang merupakan partner dalam proses pelayanan. 


\section{DAFTAR PUSTAKA}

- Fitriana,Yuni., Kurnia Sari Pratiwi. 2018. pelaksanaan patient safety di rumah sakit umum daerah dan rumah sakit umum swasta bantul berdasarkan ketentuan undangundang nomor 44 tahun 2009 tentang rumah sakit. Jurnal Kebidanan, 7 (1), 2018, 28 39.

- Juniarti,Nanda Hani., Ahmad Ahid Mudayana. 2018. Penerapan Standar keselamatan Pasien di Rumah Sakit Umum. Jurnal Kesehatan Poltekkes Ternate, 11(2), 2018, Pages $93-108$.

- Tria Harsiwi Nurul Insani,Sri Sundari. 2018. Analisis Pelaksanaan Keselamatan Pasien oleh Perawat. Journal of Health Studies, Vol. 2, No. 1 Maret 2018, Hal.84-95

- Firawati,Aumas Pabuty,Abdi Setia Putra. 2012. Pelaksanaan Programkeselamatan Pasien Di Rsud Solok. Jurnal Kesehatan Masyarakat, Maret 2012-September 2012, Vol. 6, No.2.

- Masyitoh Basabih. 2017. Perlukah Keselamatan Pasien Menjadi Indikator Kinerja RS BLU?. Jurnal Administrasi Rumah Sakit Indonesia. Volume 3, Nomor 2.

- Reno Afriza Neri, Yuniar Lestari, dan Husna Yetti. 2018. Analisis Pelaksanaan Sasaran Keselamatan Pasien Di Rawat Inap Rumah Sakit Umum Daerah Padang Pariaman. Jurnal Kesehatan Andalas.7(Supplement 4).

- Kholifatun Islami, Septo Pawelas Arso, Daru Lestantyo. 2018. Analisis Pelaksanaan Program Keselamatan Pasien Puskesmas Mangkang, Kota Semarang. Jurnal Kesehatan Masyarakat (E-Journal) Volume 6, Nomor 4, Agustus 2018 (Issn: 23563346).

- Reisia Palmina Brahmana, Kurnia Wahyudi, Lukman Hilfi. 2018. Perspektif Tenaga Kesehatan: Budaya Keselamatan Pasien pada Puskesmas PONED di Kota Bandung. JSK, Volume 3, Nomor 3 Maret.

- Najihah. 2018. Budaya Keselamatan Pasien Dan Insiden Keselamatan Pasien Di Rumah Sakit: Literature Review. Journal Of Islamic Nursing. Vol.3,No.1.

- Awaliyah Ulfah Ayudytha Ezdha, Silvia Nora Anggreini, Dwi Elka Fitri. 2018. Pengaruh Pelatihan Keselamatan Pasien Dengan Metode Ceramah Terhadap Pemahaman Perawat Mengenai Penerapan Sasaran Keselamatan Pasien Di Rs Pmc Pekanbaru. Health Care : Jurnal Kesehatan 7(2) Desember 2018 (1-8).

- Simamora, R. H., \& Fathi, A. (2019). The Influence Of Training Handover Based SBAR Communication For Improving Patients Safety. Indian journal of public health research \& development, 10(9), 1280-1285 